\title{
Principal components analysis of the chemical attributes of the soil of a preserved Cerrado fragment
}

The number of studies on the importance of Cerrado soil to biogeochemical cycles is growing, with this being the focus of most research in the Cerrado biome. The objective of this research was to verify the correlation among different chemical attributes of the soil in a Cerrado fragment located in Mãe Bonifácia Park, in Cuiabá, Mato Grosso (MT), Brazil, using principal components analysis. For this study, five soil samples were collected at 0-10 cm depth monthly from August 2015 to July 2016. After the collection and identification of the soil, chemical analyses were performed to determine the following chemical characteristics of the soil: organic matter (OM), base saturation (V\%), sum of bases (SB), cation exchange capacity (CTC), pH, and concentrations of $\mathrm{H}+, \mathrm{Al} 3+, \mathrm{Ca} 2+, \mathrm{Mg} 2+, \mathrm{K}+, \mathrm{P}, \mathrm{S}, \mathrm{Cu}, \mathrm{Mn} 2+$, $\mathrm{Mg} 2+, \mathrm{Zn}, \mathrm{Fe} 2+$ and B3+. The soil was characterized as acidic, which is typical for Cerrado soils, although some chemical elements were found in high concentrations. After the analysis of principal components, it was possible to reduce the seventeen original variables to four principal components that represented $88.86 \%$ of the total variation of the data. In which the first main component explained $41.18 \%$, the second component explained $28.39 \%$, the third $11.29 \%$ and the fourth explained $7.98 \%$. Based on this analysis, it was identified that the chemical attributes such as the sum of base (SB), organic matter (OM), cation exchange capacity (CTC), calcium ( $\mathrm{Ca} 2+)$, saturation (V\%) and $\mathrm{pH}$ represented the greater data variance.

Keywords: Biogeochemical; Soil chemistry; Mãe Bonifácia Park.

\section{Análise de componentes principais dos atributos químicos do solo de um fragmento preservado de Cerrado}

\begin{abstract}
É crescente os estudos relacionados a importância do solo do Cerrado para os ciclos da natureza, tendo este importante papel nas funções ecossistêmicas como por exemplo, os ciclos biogeoquímicos. O objetivo desta pesquisa foi verificar a correlação entre atributos químicos do solo de um fragmento de Cerrado localizado no parque Mãe Bonifácia, em Cuiabá-MT, por meio da técnica de análise de componentes principais. Para esse estudo foram coletadas cinco amostras de solo com profundidade de $0-10 \mathrm{~cm}$, mensalmente no período de agosto de 2015 a julho de 2016, totalizando 12 coletas. Após a coleta e identificação, realizou-se à análise química para determinação dos seguintes atributos do solo (MO, V\%, SB, CTC, pH, H+, Al3+, Ca2+, Mg2+, K+, P, S, Cu, Mn2+, Mg2+, Zn, Fe2+e B3+). Observou-se que o solo é caracterizado como ácido, típico dos solos do Cerrado, entretanto alguns atributos tiveram uma concentração elevada. Após a análise de componentes principais, conseguiu-se reduzir as dezessete variáveis originais para quatro componentes principais que representaram $88,86 \%$ da variação total dos dados. Em que a primeira componente principal explicou $41,18 \%$, a segunda componente explicou $28,39 \%$, a terceira $11,29 \%$ e a quarta explicou $7,98 \%$. Com base ness análise, identificou-se que os atributos químicos como a soma de base (SB), matéria orgânica (MO), capacidade de troca catiônica (CTC), cálcio (Ca2+), saturação (V\%) e o pH representaram a maior variância dos dados.
\end{abstract}

Palavras-chave: Biogeoquímico; Química do solo; Parque Mãe Bonifácia.

Danielle da Silva Batista (iD)

Universidade do Estado de Mato Grosso, Brasil

http://lattes.cnpq.br/9159520263039619

http://orcid.org/0000-0001-5617-3355

danielle.batista@unemat.br

Jonathan Willian Zangeski Novais (iD

Universidade de Cuiabá, Brasil

http://lattes.cnpq.br/5665663207008673

http://orcid.org/0000-0002-6598-3138

jonathan.novais@kroton.com.br

Susana Pacheco Pereira

Universidade de Cuiabá, Brasil

http://lattes.cnpq.br/6563212513746900

http://orcid.org/0000-0003-2384-1593

susana.pachecco@gmail.com

\author{
Roberta Daniela de Souza Lauxen da Silva (iD \\ Universidade de Cuiabá, Brasil \\ http://lattes.cnpq.br/6695057034861231 \\ http://orcid.org/0000-0001-7268-2694 \\ roberta.engenhariaambiental@gmail.com \\ Thiago Fernandes \\ Universidade Federal Rural da Amazônia, Brasil \\ http://lattes.cnpq.br/5470375744541646 \\ http://orcid.org/0000-0001-7667-355X \\ thiago.ufra.pa@gmail.com \\ Valery Kessis da Silva Pires \\ Universidade de Cuiabá, Brasil \\ http://lattes.cnpq.br/844746392731716 \\ http://orcid.org/0000-0001-7333-1853 \\ valerypires@hotmail.com
}

\section{Pricila Juliana de Souza (iD \\ Universidade de Cuiabá, Brasil \\ http://lattes.cnpq.br/1774304263302532 http://orcid.org/0000-0002-6695-2261 souza.pricila123@gmail.com \\ Ana Carolina Freitas da Silva Taques Universidade de Cuiabá, Brasil http://lattes.cnpq.br/4951797307571977 http://orcid.org/0000-0002-3903-3876 anacaroltaques@hotmail.com}

Referencing this:

BATISTA, D. S.; NOVAIS, J. W. Z.; PEREIRA, S. P.; SILVA, R. D. S. L.; FERNANDES, T.; PIRES, V. K. S.; SOUZA, P. J.; TAQUES, A. C. F. S. Principal components analysis of the chemical attributes of the soil of a preserved Cerrado fragment. Nature and Conservation, v.14, n.1, p.90-100, 2021. DOI: http://doi.org/10.6008/CBPC23182881.2021.001.0010 


\section{INTRODUCTION}

The intervention of man in any natural ecosystem causes modifications to the physical and biological environment that can cause the quality of the environment to degrade (BRANCO et al., 1999). Eventually, the microbial transformations and different chemical reactions occurring in the soil can be altered, depending on the types of anthropogenic activities enacted (THEODORO et al., 2003).

Soil can be defined as a mixture of inorganic and organic materials formed by a series of intemperic processes operating on the Earth's surface, which cause the decomposition of primary rocks and minerals through the action of physical, chemical, and biogenic weathering (HUNT, 1972). The soil is the main substratum on which plants develop, and on which all living terrestrial organisms depend. It is one of the main environmental compartments receiving many pollutants that, when deposited randomly, can contribute to the progressive degradation of terrestrial, aquatic, atmospheric, and biological environments (MANAHAN, 1999).

In addition, the soil contributes to the cycling of nutrients, which is of paramount importance to the maintenance of life within ecosystems. Indeed, these are interrelated processes in which chemical elements, including all of the elements essential to life, are used in successive periods of energy fixation and circulate through the biosphere in characteristic ways, from the environment to organisms and vice versa (ODUM, 2013).

The soil quality of the Cerrado is an important factor that determines the characteristic vegetation types found in this ecosystem. The soil is deep, well-drained, and subjected to intense weathering and leaching, which makes it acidic, nutrient-poor, and contain high levels of iron and aluminum (GOMES et al., 2000). Despite the high acidity and low fertility of its soil, the Cerrado is threatened because it is the main agricultural frontier of Brazil due to its proximity to major consumer centers, flat topography, and satisfactory road structure (KER et al., 1992).

The use of land in the Cerrado is always questionable, as negative impacts caused by the misuse of the soil reduce the area that can be preserved for agricultural use, which thus requires the use of large amounts of fertilizers and pesticides to increase the limited productive capacity there. In conjunction with habitat loss and anthropogenic climate change, these activities are changing the natural nutrient cycling in this region every day.

In addition to the anthropization and intensive use of the soil of the Cerrado for agricultural production, other environmental factors can accelerate the degradation process. For example, rainfall concentrations vary throughout the year, which produces interannual variations in vegetated surfaces; for instance, in dry periods there is a great loss in leaf area (NOVAIS et al., 2018), with a risk of burning, favoring periodic spatial and temporal modifications in the albedo (NOVAIS et al., 2015, NOVAIS et al., 2016) and soil moisture and, consequently, variability in some physicochemical processes in the soil and the atmosphere of the region (BARROS et al., 2010).

Such soil properties as variation in soil texture, moisture retention, and chemical properties like $\mathrm{pH}$ 
and aluminum content determine the distributions of different tree species in the Cerrado (SOUZA et al., 2007; ASSIS et al., 2011). Soil moisture variation, for example, can cause variations in physical, chemical, and biological processes that alter soil characteristics, such as redox potential, $\mathrm{pH}$, and the content and oxidation state of iron and manganese (PEZESHKI et al., 2012), among other nutrients. The effects of these disturbances on soil properties and the microbial community can interfere with the regeneration capacity of the forest or mediate the introduction of other plants to the area (MOREIRA et al., 2004).

Thus, the objective of this study was to assess the correlations among different chemical attributes of the soil in a Cerrado fragment located in the city of Cuiabá, Mato Grosso (MT), Brazil, by means of using principal components analysis (PCA).

\section{MATERIALS AND METHODS}

\section{Study Area}

The municipality of Cuiabá has an area of $3,224.68 \mathrm{~km}^{2}$, of which $254.57 \mathrm{~km}^{2}(7.89 \%)$ is urban and 2,970.11 $\mathrm{km}^{2}$ (92.1\%) (JOAQUIM et al., 2018). It is located at an altitude of $165 \mathrm{~m}$ above sea level (a.s.l.), within the geomorphological province called the Cuiabana Depression. The regional climate is Aw, according to the Köppen climate classification system, and is characterized by being hot and humid with rains in summer and a dry season in winter, with distinct seasons (wet and dry) and an annual accumulated of 1,400 mm year-1 (ALVARES et al., 2013).

In this context, the area of study is located, the Mãe Bonifácia Urban Park (Figure 1) under the geographical coordinates $15^{\circ} 34^{\prime} 44^{\prime} \mathrm{S}$ and $56^{\circ} 05^{\prime} 016^{\prime}$ ' W, with 77.16 hectares of area, and altitude between $164 \mathrm{~m}$ and 195m (Pacheco et al., 2018) which over the years was surrounded by the expansion of the neighborhoods surrounding it (SOUZA et al., 2020).

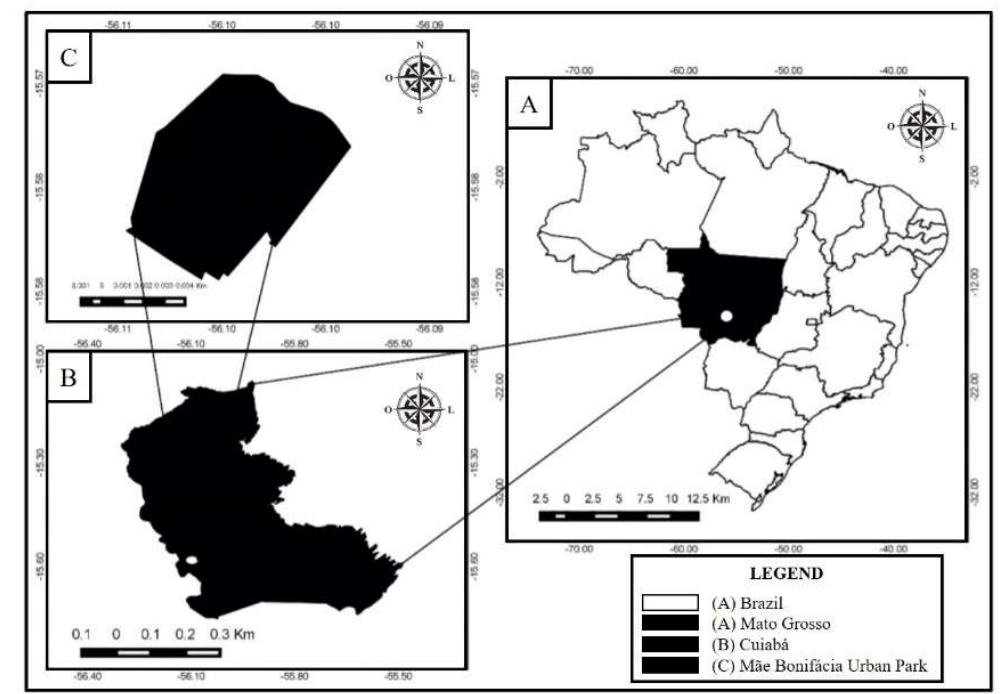

Figure 1: Location map of Mãe Bonifácia urban park in Cuiabá-MT, Brazil. Fonte: Adapted from Novais et al. (2018).

According to Andrade et al. (2016) the park is a remnant fragment of the Cerrado in its natural form, that is, without alterations resulting from relevant anthropogenic activities, having its biophysical 
characteristics preserved. The soil of the region is predominantly of the Type Concretary Cambic Alic (SCCa), characterized by being mineral soil, well drained, of medium depth, with the presence of iron concreções along the profile in an amount greater than $50 \%$ of the volume (SEPLAN, 2001).

\section{Data collect}

To cover the seasonal variability on the variables under study, 12 collections were made over a year, starting in August / 2015 and ending in July / 2016. Five collection points were established, forming a polygon defined as follows: with distances of $10.97 \mathrm{~m}$ between points 1 and 2, $15.30 \mathrm{~m}$ between points 2 and 3, 8.60 $\mathrm{m}$ between points 3 and 4, $6.60 \mathrm{~m}$ between points 3 and 4 , and $7.53 \mathrm{~m}$ between points 5 and 1 , ending the polygon.

Organic matter was removed from the soil surface before each collection, according to Arruda et al. (2014), remove leaves, sticks and other things remains from the soil surface that may compromise the quality of the sampling. The samples were taken from the first 10 centimeters of soil using an auger, weighing approximately $1 \mathrm{~kg}$ each (LEMOS et al., 1996). According to Arruda et al. (2014), states that it is necessary for samples to be taken uniformly in volume and depth. Thus, after collection, the samples were placed in identified plastic bags and stored in a refrigerated environment.

After sampling, the soil samples were sent to the laboratory for chemical analyses of their $\mathrm{CaCl}^{2}$, phosphorus $(\mathrm{P})$, potassium $\left(\mathrm{K}^{+}\right)$, calcium $\left(\mathrm{Ca}^{2+}\right)$, magnesium $(\mathrm{Mg} 2+)$, aluminum $\left(\mathrm{Al}^{3+}\right)$, hydrogen $\left(\mathrm{H}^{+}\right)$, zinc $\left(\mathrm{Zn}^{2+}\right)$, copper $\left(\mathrm{Cu}^{2+}\right)$, iron $(\mathrm{Fe} 3+)$, manganese $\left(\mathrm{Mn}^{2+}\right)$, boron $\left(\mathrm{B}^{3+}\right)$, and sulfur $\left(\mathrm{S}^{2-}\right)$ content, and their pH was also determined.

The above chemical and granulometric analyses were performed according to the EMBRAPA (1999) methodology by the laboratory in the city of Cuiabá, where the pH was determined in $\mathrm{CaCl}$ (ratio 1:2.5) and $\mathrm{P}, \mathrm{K}, \mathrm{Zn}, \mathrm{Cu}, \mathrm{Fe}$, and Mn were extracted with Mehlich-1 (0.0125 mol L-1 of $\mathrm{H} 2 \mathrm{SO} 4$ and $0.05 \mathrm{~mol} \mathrm{~L}^{-1}$ of $\left.\mathrm{HCl}\right)$ and quantified as follows: $\mathrm{P}$ was quantified by photocolorimetry, $\mathrm{K}$ using a flame photometer, and micronutrients by atomic absorption spectrophotometry. Exchangeable $\mathrm{Al}, \mathrm{Ca}$, and $\mathrm{Mg}$ were extracted with $1 \mathrm{~mol} \mathrm{~L}^{-1} \mathrm{KCl}, \mathrm{Al}$ and $\mathrm{H}$ were extracted with a $0.5 \mathrm{~mol} \mathrm{~L}^{-1}$ calcium acetate solution with a $\mathrm{pH}$ of 7 and titrated with $0.0606 \mathrm{~mol}$ $\mathrm{L}^{-1} \mathrm{NaOH}$, and $\mathrm{S}$ and $\mathrm{B}$ were extracted by turbidimetry in barium sulphate or in hot water, respectively, and both were quantified by photocolorimetry.

The sum of bases (SB), base saturation (V\%), and cation exchange capacity of the soil at a $\mathrm{pH}$ of 7 (CTC) were calculated through the sorption complex analysis.

The soil chemical parameters were chosen because they are typically reported for Cerrado soils (LOPES et al., 1977; FURLEY et al., 1988; HAASE, 1999; LILIENFEIN et al., 2003; SOUZA et al., 2007; VOURLITIS et al., 2011; WANTZEN et al., 2012).

\section{Statistics}

For the multivariate statistical analysis of correlations among soil properties, principal components analysis (PCA) was used. PCA is a multivariate statistical technique that consists of transforming a 
multidimensional set of original variables into another set of variables of the same dimensionality, called principal components (VARELLA, 2008).

The principal components identified by PCA are presented in descending order of importance, i.e. the first PC explains the maximum possible proportion of the variation in the original data, the second the maximum possible proportion of variation not yet explained by the first component, and so on, while the last component will make the least contribution to explaining the total variation in the original data (JOHNSON et al., 1998; MORRISON, 2003).

With this analysis it is possible to identify the attributes that have the greatest contribution to the composition of the studied soil. The correlation matrix was used to assess dependency, so that each variable has the same weight in obtaining the components. Then, the correlation matrix was submitted to principal component analysis, which allows transforming a set of data, initially correlated, into a new set of uncorrelated variables (NOGUEIRA et al., 2014).

The variables that will be generated are called CP (main component) and have statistical independence, that is, they are not correlated. Each CP is estimated with the purpose of retaining, in order of estimation, the total variation contained in the initial data. That is, the first main components contain most of the total variability of the data (SOUZA, 2000; REGAZZI, 2001; MANLY, 2008). ACP can be given by Equation 1.

$Z_{i}=a_{1 i} X_{1}+a_{2 i} X+\cdots+a_{n i} X_{n}$

Where: $\mathrm{Zi}$ is the $\mathrm{i}$-th main component, $\mathrm{a}_{\mathrm{ji}}$ are the coefficients of the main component, $\mathrm{X}_{\mathrm{j}}$ is the value of the $\mathrm{j}$-th variable and $\mathrm{n}$ is the number of variables (MANLY, 2008; DOMINICK et al., 2012).

All observed variables were standardized and included in the main component performance score equations. The standardization of variables is performed by the value of the variable minus the average of the group of variables assessed divided by the standard deviation, called the standard score or z-score (SILVA et al., 2015). According to equation 2:

$$
Z=\frac{\text { value of the variable-average }}{\text { standard deviation }}
$$

The eigenvalues obtained by principal component analysis were subjected to Varimax rotation, this method was developed by Kaiser in 1958. According to Johnson et al. (1998), it uses the rotation of factors to improve the interpretation of results, without changing the matrix of correlation and much less the specific variances, thereby improving the distribution of the percentage of explanation of the variance between the components.

For statistical analysis, the SPSS Statistic $21^{\circledR}$ software was used in the Principal Component Analysis (ACP) calculations, in the various calculations (eigenvalues, loads, commonality and correlation matrix).

\section{RESULTS AND DISCUSSION}

Figure 2 shows the average of the principal chemical parameters of the soil. The highest values of $P$, $\mathrm{H}, \mathrm{Fe}$ and M.O occurred in August 2015. The concentrations of $\mathrm{K}$ and $\mathrm{Ca}$ increased over time, while those of $\mathrm{P}, \mathrm{H}, \mathrm{Cu}$ and M.O tended to decrease. Ja $\mathrm{Zn}, \mathrm{Mn}$ and S did not vary their concentrations on average. 
The highest values of P, H, Fe and M.O occurred in August 2015. The concentrations of $\mathrm{K}$ and $\mathrm{Ca}$ increased over time, while those of $\mathrm{P}, \mathrm{H}, \mathrm{Cu}$ and $\mathrm{M} . \mathrm{O}$ tended to decrease. Ja $\mathrm{Zn}, \mathrm{Mn}$ and $\mathrm{S}$ did not vary their concentrations on average.

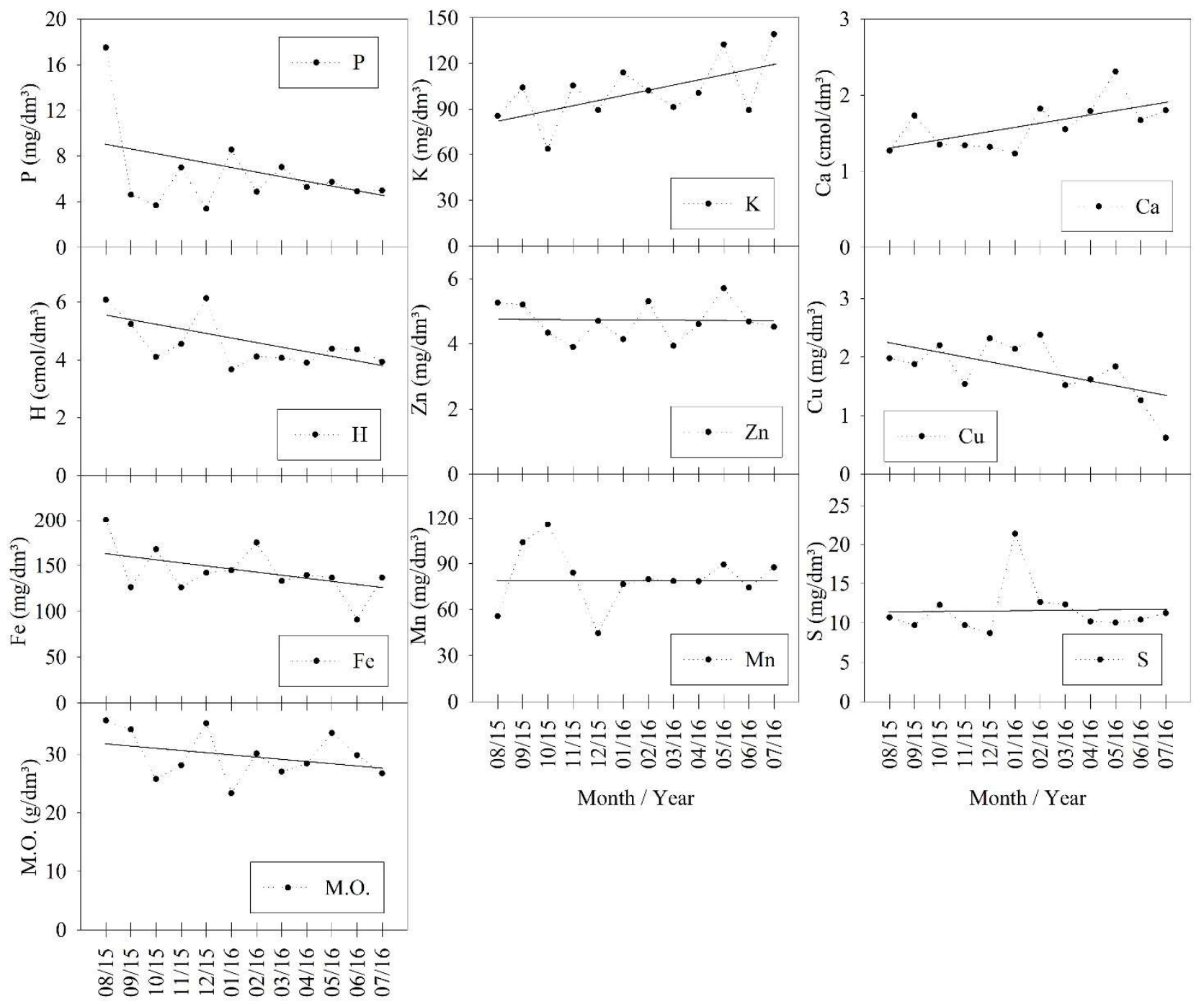

Month / Year

Figure 2: Principal soil chemical parameters of a Cerrado fragment.

The concentrations of organic matter decrease with time since the experiment started in August, a dry period for the Brazilian savannas, with leaves falling in the deciduous forests.

The principal components analysis (PCA) grouped all of the soil chemical attributes examined (17 original variables) into four main factors, as presented in table 1.

Table 1: Eigenvalues and accumulated percentage of the total variance explained by main component (CP) of the Cerrado fragment.

\begin{tabular}{llll}
\hline Components & Eigenvalues & Variance $\%$ & Cumualtive \% \\
\hline 1 & 7.002 & 41.186 & 41.186 \\
2 & 4.827 & 28.396 & 69.582 \\
3 & 1.921 & 11.298 & 80.879 \\
4 & 1.357 & 7.985 & 88.864 \\
5 & 0.731 & 4.302 & 93.166 \\
6 & 0.505 & 2.968 & 96.134 \\
7 & 0.307 & 1.805 & 97.938 \\
8 & 0.165 & 0.973 & 98.912 \\
\hline
\end{tabular}




\begin{tabular}{llll}
\hline 9 & 0.112 & 0.657 & 99.568 \\
10 & 0.6 & 0.351 & 99.919 \\
11 & 0.014 & 0.081 & 99.919 \\
\hline
\end{tabular}

Extraction method: analysis of the main component.

The PCA was overall able to explain $88.86 \%$ of the total variance in the data. This agreed with results of Johnson et al. (1998), who stated that a minimum percentage of the total variance explained close to $80 \%$ is needed to determine the appropriate number of principal components for a given dataset, while Hair et al. (2006) suggests $60 \%$.

The first principal component explained $41.18 \%$ of the total variation in the data, and thus can be considered the repository of the most important information concerning the relations among the different soil variables tested, their eigenvalues are presented in Table 1 . The second component explained $28.39 \%$ of the variation, followed by the third that explained $11,29 \%$ and the fourth $7.98 \%$. Together they explained approximately $88.84 \%$ of the total variance of the chemical attributes present in the soil of the Cerrado fragment.

The sedimentation curve can be seen in Figure 3, in which a decay is perceived up to the fourth eigenvalue, becoming almost parallel to the abscissa axis, then falling again. In this case, only one or two components could be retained, however we opted for a greater explanation of the accumulated variance of the data, thus analyzing 4 main components.

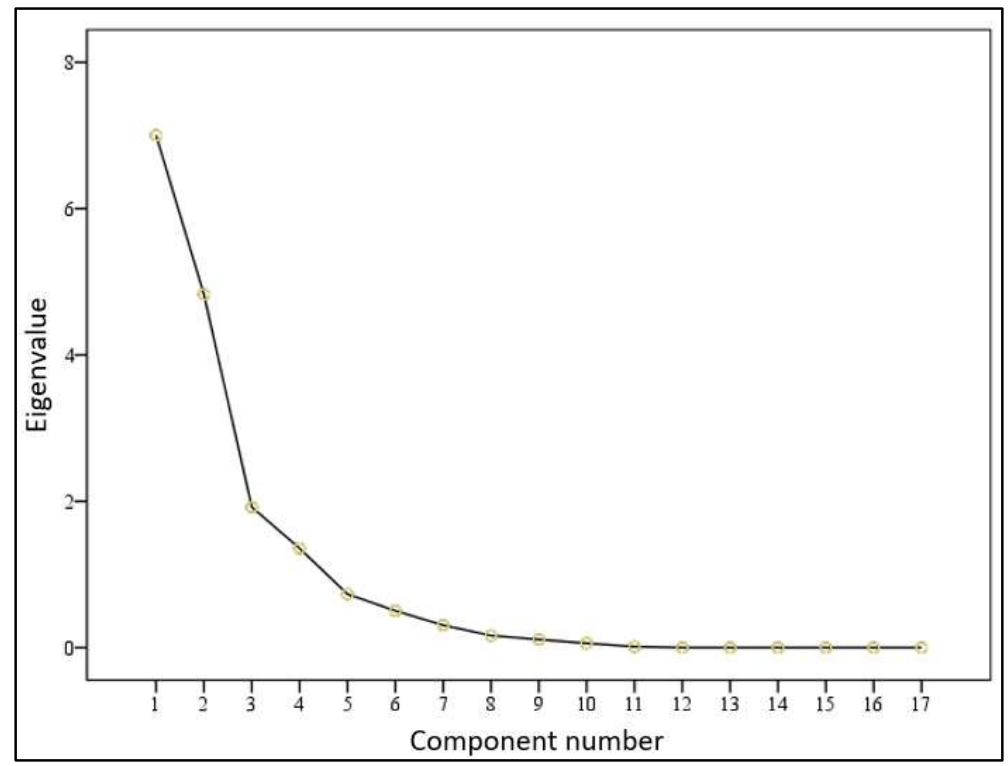

Figure 3: Sedimentation curve of the main components for the Cerrado fragment.

The literature indicates that the researcher can use the accumulated variance criterion to determine the number of factors that must be extracted. Hair et al. (2006) suggest the $60 \%$ level as being acceptable. We used the criterion of Kaiser (1958) and the first fourth components were retained, reducing from 17 to 4.

The correlation between the original variables and the main components is called loading. These provide an indication of how important the original variables are for the formation of the main components. Therefore, loadings close to 1 indicate that this variable is important in the formation of the main component, 
while loadings close to zero indicate that the variable is not important in the formation of the main component (GOMES et al., 2000).

Table 2 shows the loadings of the main components for each of the 17 variables. For each variable, the highest loading was selected, in absolute value, to understand which or which variables are most important in the formation of each of the first 4 components.

Table 2: Principal component analysis (PCA) of soil chemical variables in the Cerrado fragment.

\begin{tabular}{|c|c|c|c|c|}
\hline & \multicolumn{4}{|c|}{ Components } \\
\hline & 1 & 2 & 3 & 4 \\
\hline $\mathbf{P}$ & -0.263 & 0.002 & 0.179 & 0.858 \\
\hline $\mathbf{K}^{+}$ & 0.658 & -0.121 & -0.487 & 0.319 \\
\hline $\mathrm{Ca}^{2+}$ & 0.926 & 0.201 & -0.189 & -0.160 \\
\hline $\mathbf{H}^{+}$ & -0.390 & 0.853 & 0.159 & 0.287 \\
\hline Mo & 0.086 & 0.947 & 0.157 & 0.235 \\
\hline $\mathrm{Zn}^{2+}$ & 0.617 & 0.594 & 0.358 & 0.215 \\
\hline $\mathrm{Cu}^{2+}$ & -0.155 & 0.140 & 0.890 & -0.059 \\
\hline $\mathrm{Fe}^{2+}$ & -0.047 & -0.006 & 0.756 & 0.454 \\
\hline $\mathrm{Mn}^{2+}$ & 0.276 & -0.345 & 0.064 & -0.607 \\
\hline B & 0.175 & -0.909 & -0.052 & 0.127 \\
\hline $\mathbf{S}$ & -0.084 & -0.803 & 0.249 & 0.225 \\
\hline $\mathrm{Mg}^{2+}$ & 0.895 & 0.088 & 0.268 & -0.114 \\
\hline $\mathrm{Al}^{3+}$ & -0.930 & 0.153 & 0.211 & 0.232 \\
\hline СTC & 0.079 & 0.938 & 0.163 & 0.259 \\
\hline SB & 0.977 & 0.144 & -0.074 & -0.110 \\
\hline V (\%) & 0.914 & -0.290 & -0.137 & -0.192 \\
\hline pH & 0.914 & -0.277 & -0.112 & -0.253 \\
\hline
\end{tabular}

Extraction method: Principal component analysis.

Rotation method: Varimax with Kaiser normalization.

Figure 4 shows the graphical representations of the loadings of the first two components. In addition, the values corroborate with the results found in table 2 .

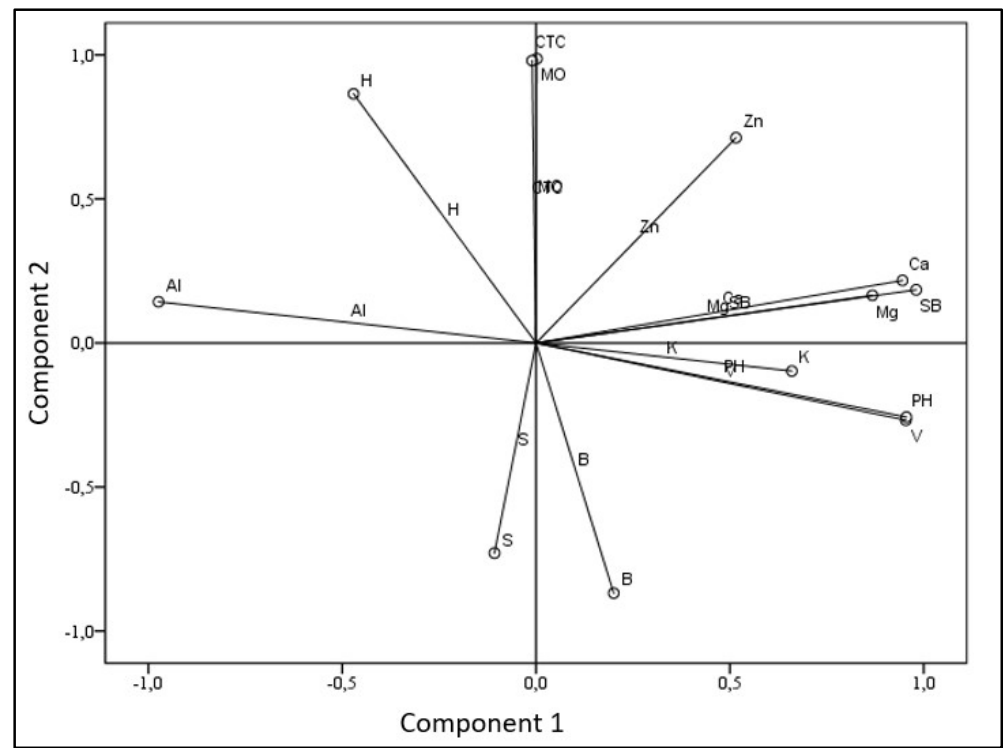

Figure 4: Graphical representation of the loadings of the first two main components.

Based on the data in Table 2 and using equation (2), the mathematical model of equation (1) used for the scores of the main components (CP1. CP2) was estimated, corresponding to approximately $69.58 \%$ of the total variation. as can be seen in equations 3 and 4 .

According to equation ( 3 ) the main values that were associated in the first component that presented 
a positive contribution between the attributes were:

$$
\begin{gathered}
C P 1=-0.263 *(P)+0.658 *(K+)+0.926 *(C a 2+)+0.617 *(Z n 2+) 0.89(M g 2+)-0.930 \\
*(A l 3+)+0.977 *(S B)+0.914 *(V \%)+0.914 \\
*(p H) \\
C P 2=0.853 *(H+)+0.947 *(M O)-0.909 *(B)-0.803 *(S)+0.938 *(C T C)
\end{gathered}
$$

The soil of the study area was characterized by its strong acidity, with an average $\mathrm{pH}$ value of $4.75 \mathrm{in}$ $\mathrm{CaCl}^{2}$. The soil's sum of bases (SB), base saturation (V\%), and concentrations of calcium $(\mathrm{Ca} 2+)$, magnesium $\left(\mathrm{Mg}^{2+}\right)$, potassium $(\mathrm{K}+)$, and zinc $\left(\mathrm{Zn}^{2+}\right)$ were all positively correlated within the first principal component, while the aluminum $\left(\mathrm{Al}^{3+}\right)$ concentration was correlated negatively with the other variables in the first component (Table 2). These findings agreed with the results of Vourlitis et al. (2013), who evaluated the fertility of the Cerrado soil.

Based on the PCA results, when the soil's capacity to retain cations increased, there was a simultaneous increase in its SB (Table 2). In the system under study this was likely mainly due to the increased presence of $\mathrm{Ca}^{2+}$ in the sortative complex (VALADÃO, 2015), as suggested by the relationships among variables within the first principal component. As the soil exchange complex grows richer in bases, especially with $\mathrm{Ca}^{2+}$, the $\mathrm{pH}$ rises, which neutralizes Al3+ (VALADÃO, 2015). The $\mathrm{pH}$ influences the solubility, solution concentration, and ionic forms of the nutrients in the soil and consequently their absorption and use by plants.

The second component explained $28.39 \%$ of the total variation in the data (Table 1 ) and contained mainly positive eigenvalues for the variables hydrogen $(\mathrm{H}+)$, organic matter $(\mathrm{OM})$ and cation exchange capacity (CTC) (Table 2). The increase in CTC as a function of OM indicated by this positive correlation likely occurred due to the generation of negative charges by the break in the $\mathrm{C}$ chains that form the radicals $\mathrm{R}-\mathrm{COH}$ (carboxyl) and R-OH (hydroxyl) on the surfaces of OM (RAIJ. 1991). Further. $\mathrm{H}^{+}$(hydrogen) content is already known to be an essential mediator of the survival of organic matter in the soil (EBELING et al., 2008).

Boron and sulfur concentrations were correlated negatively (Table 2) with the other variables in the second component. This result is directly related to the mineralization of organic matter in the soil. Which is lower during drier periods and also to the decreased adsorption of this nutrient during such periods since it occurs through mass flow (MALAVOLTA et al., 1985).

The third principal component comprised the micronutrients copper and iron which together explained $11.29 \%$ of the variation in the data (Table 1 ) and were positively correlated with one another (Table 2). This correlation is related to several metabolic activities in plants, as $\mathrm{Cu}$ and Fe participate in the formation of several enzymes (e.g. catalase, peroxidase, cytochrome oxidase, and xanthine oxidase), and are also indispensable in the processes of respiration photosynthesis, N2 fixation and electron transfer through cycling between $\mathrm{Fe}^{2+}$ and $\mathrm{Fe}^{3+}$ (GUERINOT et al., 1994; MARENCO et al., 2009).

The fourth and last principal component represented $7.98 \%$ of the total variation in the data (Table 1) and comprised the main nutrients phosphorus $(P)$ and manganese $(\mathrm{Mn})$ which were negatively correlated with each other (Table 2). This may be related to the fact that the soil availability of manganese is reduced 
by increased $\mathrm{pH}$ as well as high levels of organic matter, phosphorus, copper, and zinc, which result in elemental complexion (RAIJ, 1991).

\section{CONCLUSIONS}

In view of the results obtained the analysis of main components proved to be effective. Thus, fewer variables were necessary to explain the total variation without significant loss of information. Therefore, the principal component analysis reduced the 17 original variables $\left(\mathrm{MO}, \mathrm{V} \%, \mathrm{SB}, \mathrm{CTC}, \mathrm{pH}, \mathrm{H}^{+}, \mathrm{Al}^{3+}, \mathrm{Ca}^{2+}, \mathrm{Mg}^{2+}, \mathrm{K}\right.$, $\mathrm{P}, \mathrm{S}, \mathrm{Cu}, \mathrm{Mn}^{2+}, \mathrm{Mg}^{2+}, \mathrm{Zn}^{2+}, \mathrm{Fe}$ and $\mathrm{B}$ ) for four main components that represented $88.86 \%$ of the total data variation.

The first component explained $41.18 \%$. The $\mathrm{pH}$ contributed significantly to the variables of the first component. The second component explains $28.39 \%$ of the total variation. In the third component formed by the micronutrients copper and iron. The variation was explained by $11.29 \%$. The fourth component explained $7.98 \%$ of the total variance, corresponding to the elements phosphorus and manganese.

Attributes such as base sum (SB), organic matter (OM), cation exchange capacity (CTC), calcium $\left(\mathrm{Ca}^{2+}\right)$, saturation $(\mathrm{V} \%)$ and $\mathrm{pH}$ represented most of the data variance.

\section{REFERENCES}

ALVARES, C. A.; SATAPE, J. L.; SENTELHAS, P. C.; GONÇALVES, J. L. M.; GERD, S.. Köppen's climate classification map for Brazil. Meteorologische Zeitschrift, Sttutgart, v.22, n.6, p.711-728, 2013.

ANDRADE, L. P.; NOVAIS, J. W. Z.; MUSIS, C. R.; SANCHES, L.; PEREIRA, S. P.. Edge effects on the microclimate of an urban ecological park in Cuiabá-MT. Revista Estudo e Debate, Lajeado, v.23, n.2, 2016.

ARRUDA, M. R.; MOREIRA, A.; PEREIRA, J. C. R.. Amostragem e cuidados na coleta de solo para fins de fertilidade. Embrapa Amazônia Ocidental, 2014.

ASSIS, A. C. C.; COELHO, R. M.; PINHEIRO, E. S.; DURIGAN, G.. Water availability determines physiognomic gradient in an area of low-fertility soils under Cerrado vegetation. Plant Ecology, v.212, p.1135-1147, 2011.

BARROS, M. P. B.; NOGUEIRA, M. C. J. A.; MUSIS, C. R.. O projeto de parque urbano e os riscos da exposição ao calor. Ambiente Construído, Porto Alegre, v.10, n.2, p.147-156, 2010.

BRANCO, S. M.; CAVINATTO, V. M.. Solos: a base da vida terrestre. São Paulo: Moderna. 1999.

DOMINICK, D.; JUAHIR, H.; LATIF, M. T.; ZAIN, S. M.; ARIS, A. Z.. Spatial assessment of air quality patterns in Malaysia using multivariate analysis. Atmospheric Environment, v.60, p.172-181, 2012. DOI:

http://dx.doi.org/10.1016/j.atmosenv.2012.06.021

EBELING, A. G.; ANJOS, L. H. C.; PEREZ, D. V.; PEREIRA, M. G.; VALLADARES, G. S.. Relação entre acidez e outros atributos químicos em solos com teores elevados de matéria orgânica.
Bragantia, Campinas, v.67, n.2, p.429-439, 2008.

EMBRAPA. Empresa Brasileira de Pesquisa Agropecuária. Manual de análises químicas de solos. Plantas e fertilizantes. Brasília: Embrapa, 1999.

FURLEY, P. A.; RATTER, J. A.. Soil resources and plant communities of the central Brazilian cerrado and their development. Journal of Biogeography, Zurich, v.15, p.97$108,1988$.

GOMES, M. A. N.; SHEPHERD, S. L. K.. Estudo de nutrição mineral in vitro relacionado à adaptação de Sinningia allagophylla (Martius) Wiehler (Gesneriaceae) às condições de cerrado. Revista Brasileira de Botânica, São Paulo, v.23, n.2, p.153-159, 2000.

GUERINOT, M. A.; YI, Y.. Iron: nutritious, noxious and not readily available. Plant Physiology, v.104, p.815-820, 1994.

HAASE, R.. Litterfall and nutrient return in seasonally flooded and nonflooded forest of the Pantanal. Mato Grosso. Brazil. Forest Ecology and Management, v.117, p.129-147, 1999.

HUNT, C. B.. Geology of soils: their evolution, classification and uses. 1972.

JOAQUIM, T. D.; NOVAIS, J. W. Z.; ANDRADE, L. P.; ROSSETI, K. A. C.; VILANI, M. T.; PEREIRA, S. P.. Thermo-hygrometric modeling using ENVI-met ${ }^{\circledR}$ software to an urban park in Cuiabá - Brazil. Ciência e Natura, Santa Maria, v.40, e37, 2018.

JOHNSON, R. A.; WICHERN, D. W.. Applied multivariate statistical analysis. 4 ed. New Jersey: Prentice-Hall, 1998. 
KER, J. C.; PEREIRA, N. R.; CARVALHO JUNIOR, W.; CARVALHO-FILHO, A.. Cerrados: solos. Aptidão e potencialidade agrícola. In: SIMPÓSIO SOBRE MANEJO E CONSERVAÇÃO DO SOLO NO CERRADO. Anais Campinas: Fundação Cargill, 1992. p.1-28.

LEMOS, R. D.; SANTOS, R. D.. Manual de descrição e coleta de solo no campo. Campinas: Sociedade Brasileira de Ciência do Solo, 1996.

LILIENFEIN, J.; WILCKE, W.; VILELA, L.; AYARZA, M. A.; CARMO, L. S.; ZECH, W.. Soil fertility under native cerrado and pasture in the Brazilian savanna. Soil Science Society of America Journal, v.67, p.1195-1205, 2003.

LOPES, A. S.; COX, F. R.. Cerrado vegetation in Brazil: an edaphic gradient. Agronomy Journal, Madison, v.69, p.828831, 1977.

MALAVOLTA, E.; KLIESMANN, H. J.. Desordens nutricionais no cerrado. Piracicaba: Potafós, 1985.

MANAHAN, S. E.. Environmental chemistry. 7 ed. Boca Raton: Lewis Publishers, 1999.

MARENCO, R. A.; LOPES, N. F.. Fisiologia vegetal: fotossíntese, respiração, relações hídricas e nutrição mineral. Viçosa: Universidade Federal de Viçosa, 2009.

MOREIRA, A.; COSTA, D. G.. Dinâmica da matéria orgânica na recuperação de clareiras da floresta amazônica. Pesquisa Agropecuária Brasileira, Brasília, v.39, n.10, p.1013-1019, 2004.

MORRISON, D. F.. Multivariate statistical methods. 4 ed New York: Duxbury Press. 2003.

NOVAIS, J. W. Z.; SANCHES, L.; SILVA, L. B.; MACHADO, N. G.; AQUINO, A. M.; RODRIGUES, T. R.. Variação horária e sazonal da radiação solar incidida e refletida e suas relações com variáveis micrometeorológicas no Pantanal Norte Matogrossense. Revista Brasileira de Ciências Ambientais, Rio de Janeiro, v.38, p.96-108, 2015.

NOVAIS, J. W. Z.; SANCHES, L.; SILVA, L. B.; MACHADO, N. G.; AQUINO, A. M.; PINTO JUNIOR, O. B.. Albedo do solo abaixo do dossel em área de Vochysia divergens Pohl no norte do Pantanal. Revista Brasileira de Meteorologia, São José dos Campos, v.31, n.2, p.157-166, 2016.

NOVAIS, J. W. Z.; SANCHES, L.; DIAS. V. M.; MACHADO, N. G.; SILVA, L. B.; AQUINO, A. M.. Variação espaço-temporal da PAR refletida pelo solo e transmitida pelo dossel em floresta inundável no pantanal mato-grossense. Ciência Florestal, Santa Maria, v.28, n.4, p.1502-1513, 2018.

NOVAIS, J. W. Z.; MARQUES, A. C. A.; SIQUEIRA, A. Y.; REIS, N. M. S.; PEREIRA, S. P.; THIAGO, D.; ZANGESKI, D. D. S. O.. Índice de Temperatura e Umidade (ITU) visando o conforto térmico para o Parque Mãe Bonifácia. Ensaios e Ciência, Cuiabá, v.22, n.2, p.69-75, 2018. DOI: http://dx.doi.org/10.17921/1415-6938.2018v22n2p69-75

ODUM, E. P.. Ecologia. Rio de Janeiro: Guanabara Koogan, 2013.

PEZESHKI, S. R.; DELAUNE, R. D.. Soil oxidation-reduction in wetlands and its impact on plant functioning. Biology, v.1, p.196-221, 2012

RAIJ, B. V.. Fertilidade do solo e adubação. Agronômica Ceres. Piracicaba: Associação Brasileira para a Pesquisa da Potassa e do Fosfato, 1991.

SEPLAN. Mapa de Solos do Estado de Mato Grosso: Zoneamento Sócio-Econômico Ecológico. SEPLAN, 2001

SOUZA, J. P.; ARAUJO, G. M.; HARIDASAN, M.. Influence of soil fertility on the distribution of tree species in a deciduous forest in the Triangulo Mineiro region of Brazil. Plant Ecology, v.191, p.253-263, 2007.

SOUZA, R. D.; NOVAIS, J. W. Z.; PIERANGELI, M. A. P.; LANSSANOVA, M. D.; FERNANDES, T.; HOKI, V. S. P.; SOUZA, P. J.. Urban microclimate in vegetated and non-vegetated areas in wet and dry periods. Raega-O Espaço Geográfico em Análise, v.47, n.1, p.136-149, 2020.

THEODORO, V. C. A.; ALVARENGA, M. I. N.; GUIMARÃES, R. J.; MOURÃO JÚNIOR, M.. Carbono da biomassa microbiana e micorriza em solo sob mata nativa e agroecossistemas cafeeiros. Acta scientiarum: agronomy. Maringá, v.25, n.1, p.147-153, 2003.

VALADÃO, F. C. D. A.. Análise multivariada na avaliação da fertilidade de solos de Mato Grosso. Dissertação (Mestrado em Agricultura Tropical) Universidade Federal de Mato Grosso, Cuiabá, 2010.

VARELLA, C. A. A.. Análise multivariada aplicada as ciências agrárias. Seropédica: Universidade Federal Rural do Rio de Janeiro. 2008.

VOURLITIS, G. L.; LOBO, F. A.; LAWRENCE, S.; LUCENA, I. C.; DALMAGRO JUNIOR, O. B. P.; ORTÍZ, C. E. R.; NOGUEIRA, J. S.. Variations in stand structure and diversity along a soil fertility gradient in a Brazilian savanna (Cerrado) in southern Mato Grosso. Soil Science Society of America Journal, v.77, n.4, 2013

VOURLITIS, G. L.; ROCHA, H. R.. Flux dynamics in the Cerrado and Cerrado-Forest Transition of Brazil. In: HILL, M. J.; HANAN, N. P.. Ecosystem function in global savannas: measurement and modeling at landscape to global scales. Boca Raton: CRC Research Press, 2011. p.97-116.

WANTZEN, K. M.; COUTO, E. G.; MUND, E. E.; AMORIM, R. S. S.; SIQUEIRA, A.; TIELBÖRGER, K.; SEIFAN, M.. Soil carbon stocks in stream-valley ecosystems in the Brazilian Cerrado Agroscape. Agriculture. Ecosystems \& Environment, v.151, p.70-79, 2012.

A CBPC - Companhia Brasileira de Produção Científica (CNPJ: 11.221.422/0001-03) detém os direitos materiais desta publicação. Os direitos referem-se à publicação do trabalho em qualquer parte do mundo, incluindo os direitos às renovações, expansões e disseminações da contribuiç̃o, bem como outros direitos subsidiários. Todos os trabalhos publicados eletronicamente poderão preservam os direitos autorais, mas não têm permissão para a publicação da contribuição em outro meio, impresso ou digital, em português ou em tradução. 